\title{
Regulatory Imperatives for Renewable Energy: South African Perspectives
}

\author{
Tumai Murombo* (1) \\ University of the Witwatersrand, Johannesburg, South Africa \\ tmurombo@gmail.com
}

\begin{abstract}
Access to affordable, reliable and sustainable energy is a pre-condition for sustainable economic development. This is the case in South Africa, where the workforce and entrenched fossil fuel industry remain sceptical about a transition to renewable energy. This article explores the complexity of energy regulation in countries with a deep-seated economic dependency on fossil fuels. South Africa presents a good case study of the challenge of balancing the environmental, social and economic imperatives of energy. It unpacks the drivers behind directed regulation towards renewable electricity. A painful, but necessary, "just transition" to a low-carbon economy requires laws to phase-out fossil fuels, without exposing public funds to private profit seekers. The South African experience of renewable electricity demonstrates the challenges of regulatory uncertainty. Careful legal reforms are necessary to rid existing electricity laws of their inertia and achieve a low-carbon economy while ensuring access to affordable, reliable and environmentally sustainable energy.
\end{abstract}

\section{Keywords}

Energy law and regulation, just transition, low-carbon economy, renewable energy procurement, South Africa

\section{INTRODUCTION}

The entrenchment of conventional fossil fuels was accomplished by a legal system that legitimized and perpetuated their domination. ${ }^{1}$ In order to dislodge that status quo, energy law and current reforms to encourage renewable energy in South Africa are not articulated within a nuanced regulatory

* Professor of law, School of Law, University of the Witwatersrand, South Africa. LLB (hons) (University of Zimbabwe), LLM (Cape Town), LLM (Pace University) and PhD (Witwatersrand). This article is based on T Murombo "Promoting sustainable (renewable) energy in an age of inertia: South African views" (paper presented at the 17th IUCN Academy of Environmental Law Colloquium, 4-9 August 2019, Kuala Lumpur, Malaysia). Conference attendance was partly supported by the National Research Foundation of South Africa, grant no 1091780.

1 C Mitchell and B Woodman "Regulation and sustainable energy systems" in R Baldwin, M Cave and M Lodge (eds) The Oxford Handbook of Regulation (2010, Oxford University Press) 572 at 583. 
theoretical foundation. Targeted legal regulation ${ }^{2}$ is crucial to establishing a viable renewable energy industry that can contribute sustainably to South Africa's energy mix. ${ }^{3}$ Without focused legal regulation, no monopolies would have arisen and energy markets would have evolved differently. It is also possible to allow free market forces to shape the renewable energy sector without legal regulation. While economists largely explain monopolies on the basis of market forces, it is submitted that an environment that allows the development of utility monopolies includes the legal and institutional superstructure within which they operate. Once mature, laws and institutions that regulate the existing energy system reinforce that system, which becomes so entrenched that it is difficult to reform the laws and institutions without changing the market environment. ${ }^{4}$

The relationship between energy production processes and resultant environmental problems requires integrated regulation, especially in respect of renewable electricity and the global and local problems that renewable energy is likely to solve. While legal regulation per se will not clean the air and the waters of the earth completely, it can at least ensure that we understand the extent to which the energy sector is affecting the environment and thereby the degree to which we can leverage energy resources to promote environmentally sustainable development. ${ }^{5}$ The latter implies a low-carbon economy that is just, in a distributive, procedural, restorative and social equity sense. ${ }^{6}$

This article hypothesizes that, without effective legal regulation, the electricity supply industry will be locked further into fossil fuels. ${ }^{7}$ Secondly, in the absence of legal regulation, it will take longer for the electricity supply industry to transition justly to renewables. There is a strong link between energy, the economy, the environment and society. This area of convergence must be exploited to the benefit of every sector, in particular to address global

2 R Baldwin, C Scott and C Hood "Introduction" in R Baldwin, C Scott and C Hood (eds) A Reader on Regulation (1998, Oxford University Press) 1 at 2-3, discussing the three main meanings of regulation.

3 The law provides security for investments, guarantees rights, creates incentives like subsidies and feed-in-tariffs, and enables long-term energy planning. See A Eberhard, J Kolker and J Leigland "South Africa's renewable energy IPP procurement program: Success factors and lessons" (2014, World Bank) at 7; C Mitchell The Political Economy of Sustainable Energy (2008, Palgrave) at 2 (current paradigm constraint innovation); A Eberhard "From state to market and back again: South Africa's power sector reforms" (2005) Economic and Political Weekly 5316; Department of Energy "Outcomes of the national energy summit" (25-27 September 2007) at 66; S Nel "Transforming the energy supply industry" (2012) 64 FOCUS at 15, 21 and 41.

$4 \quad$ Mitchell and Woodman "Regulation and sustainable energy", above at note 1 at 584.

5 D Helm Energy, the State, and the Market: British Energy Policy Since 1979 (2004, Oxford University Press) at 12.

6 D McCauley and R Heffron "Just transition: Integrating climate, energy and environmental justice" (2018) 119 Energy Policy 1 at 3-4.

7 Id at 12, adding that "market-based instruments are not always the best route, and sometimes more direct regulation is needed". 
and domestic environmental problems, with a focus on the most vulnerable, the energy-poor and the labour force. This article concisely unpacks why legal regulation is necessary to promote such a transition. While it uses the example of South Africa, the challenges with the role and function of law in the transition are typical of countries heavily dependent on fossil fuels.

The article begins by elaborating the regulatory context, outlining the current energy situation in South Africa within the intricate interlinkages noted above, and then shifts to discuss the drivers for stronger regulation. ${ }^{8}$ The article then presents a review and analysis of the proposed justifications for using legal regulation to promote renewable energy and characterizes the functions of such regulation. It concludes with recommendations on key features of a law that could enable the energy transition. Broader and deeper analysis of the implementation of such reforms, and the various regulatory instruments that could be embedded, are beyond the limited scope of this study. ${ }^{9}$

\section{SETTING THE CONTEXT}

While analysing the legal challenges to a progressive renewable energy legal framework in South Africa, this study does not tackle all the challenges. First, by way of context and trends, while energy is indispensable for socioeconomic growth (development), ${ }^{10}$ this growth could be hampered by the lack of an effective, socially equitable facilitative legal framework to promote sustainable renewable energy. ${ }^{11}$ Thus, Lyster and Bradbrook rightly noted that:

"[T]he extent to which sustainable energy technologies are adopted in Australia and elsewhere depends on a variety of largely unrelated factors. The most important of these are the degree of research activity conducted by private and public research institutions; the level of government assistance provided, the economics of renewable energy and energy efficient technologies, the degree of social acceptance of alternative energy technologies and the level of public education in issues of sustainable development. Another important, and sometimes overlooked, factor is the role of law."12

8 The sections on regulatory context, justification and drivers for regulation draw largely from chap 2 of the author's doctoral thesis: T Murombo "Law, regulation, and the promotion of renewable energy in South Africa" (submitted to the University of the Witwatersrand, 2016, as updated).

9 See generally, MI al Irsyad et al "Selecting tools for renewable energy analysis in developing countries: An expanded review” (2017) 5 Frontiers in Energy Research 34.

10 YO Omorogbe "Promoting sustainable development through the use of renewable energy: The role of the law" in DN Zillman et al (eds) Beyond the Carbon Economy: Energy Law in Transition (2008, Oxford University Press) 39 at 41.

11 S Carleyolsen "Tangled in the wires: An assessment of the existing US renewable energy legal framework" (2006) 46 Natural Resources Journal 759 at 760; IS Russell "The sustainability principle in sustainable energy" (2008) 44 Tulsa Law Review 121 at 121.

12 R Lyster and AJ Bradbrook Energy Law and the Environment (2006, Cambridge University Press) at 28-29 (emphasis added). 
These sentiments resonate with equal force in respect of South Africa, as the function of law in promoting renewables is not necessarily affected by jurisdictional constraints.

Lyster and Bradbrook conclude by unequivocally arguing that, in addition to playing the regulatory function, law is indispensable in addressing the identified challenges. ${ }^{13}$ The role that law plays in promoting renewable energy is visible in jurisdictions such as Germany, ${ }^{14}$ Spain, ${ }^{15}$ Denmark $^{16}$ and China ${ }^{17}$ that have made renewable energy a major component in their energy mixes. Similarly, renewable energy can only play a significant role with the support of decisive and predictable regulation, albeit imperfectly designed in some of these countries. However, blindly using publicly funded incentives, such as feed-in-tariffs, or other subsidized systems without proper long-term sustainable planning can recreate inequalities and lock the country into costly renewable energy contracts, while saddling the public utility with the costs of unprofitable transmission, grid stabilization and storage functions.

Secondly, the South African legal environment is not currently conducive to the large-scale commercial deployment of renewable energy in the electricity sector, which is the primary focus of this article. To promote sustainable development through economic growth, South Africa should create a legal environment to enable the proportion of renewable energy sources to increase gradually. Various approaches can be adopted that merit further detailed investigation. For now, this article only discusses the antecedents of such a framework. However, the fact that strategies have worked with varying degrees of success elsewhere is no guarantee that they will work in the South African social, economic, governance and political environment. ${ }^{18}$ Nevertheless, this

13 Id at 30; GE Marchant "Sustainable energy technologies: Ten lessons from the history of technology regulation” (2009) 18 Widener Law Journal 831 at 831.

14 Renewable Energy Sources Act of 2008 (EEG), act implementing Directive 2001/77/EC of the European Parliament and European Council of 27 September 2001 on the promotion of electricity produced from renewable energy sources in the internal electricity market (OJ L 283 at 333), as last amended by Directive 2006/108/EC of the European Council of 20 November 2006 (OJ L 363 at 414).

15 A Ciarreta, MP Espinosa and C Pizarro-Irizar "Is green energy expensive? Empirical evidence from the Spanish electricity market” (2014) 69 Energy Policy 205 at 210. The intention is not to embark on extensive comparative analysis, but successful countries are cited for illustrative purposes.

16 Danish Energy Association Danish Electricity Supply, Statistics (2001) at 31 and 32; Electricity Supply Act 1999; Act on Utilization of Renewable Energy, Act 302 of 16 May 1990, sec 10A; and Order No 270 of 2 May 1991 on Type Approval and Certification of Wind Turbines.

17 "China passes Renewable Energy Law" (3 September 2005) Renewable Energy World, available at: <http://www.renewableenergyworld.com/rea/news/article/2005/03/china-pass es-renewable-energy-law-23531> (last accessed 3 May 2021), analysed in detail in S Schuman and A Lin "China's Renewable Energy Law and its impact on renewable power in China: Progress, challenges and recommendations for implementation" (2012) 51 Energy Policy 89 at 90.

18 See generally A Bublitz, D Keles and W Fichtner "An analysis of the decline of electricity spot prices in Europe: Who is to blame?” (2017) 107 Energy Policy 323. 
article argues that, as a starting point, these strategies are desirable approaches that must be analysed and contextualized, beginning with a justification of the need for regulation.

The third contextual aspect is that South Africa remains one of the largest greenhouse gas (GHG) emitters, being 14th (with 1.3 per cent) on the world's list of top GHG emitters, mainly from electricity generation. ${ }^{19}$ While South Africa is not legally bound to take steps to reduce its GHG emissions (being a non-Annex I developing country member of the UN Framework Convention on Climate Change (UNFCCC) and the Kyoto Protocol to the UNFCCC), ${ }^{20}$ its courts have ruled that, before approving new coal-fired power plants, a climate change assessment is required as part of the environmental authorization process. ${ }^{21}$ In any case, the country has reporting and good faith obligations. ${ }^{22}$ Persistent heavy reliance on conventional fossil sources could be construed as contrary to South Africa's obligations under international laws governing climate change and GHG emissions. Beyond the treaties noted above, South Africa committed to intended nationally determined contributions (NDCs) in $2015^{23}$ under the Paris Agreement on Climate Change, creating self-imposed obligations to mitigate emissions. These international imperatives must therefore act as push factors towards a transition to more renewables in the energy mix. ${ }^{24}$ Furthermore, these global trends call for targeted regulation, although the International Energy Agency (IEA) noted that global $\mathrm{CO}_{2}$ emissions from energy flattened in $2019 .{ }^{25}$

19 World Economic Forum "Chart of the day: These countries create most of the world's $\mathrm{CO}^{2}$ emissions" (7 June 2019), available at: <https://www.weforum.org/agenda/2019/06/chart-ofthe-day-these-countries-create-most-of-the-world-s-co2-emissions/> (last accessed 3 May 2021); see also Department of National Treasury "Reducing greenhouse gas emissions and facilitating the transition to a green economy: Carbon tax policy paper" (2013) at 19.

20 "Reducing greenhouse gas emissions", ibid. In Copenhagen at the Conference of the Parties (COP) 16 of the UNFCCC, South Africa voluntarily undertook to reduce its GHG emissions by $34 \%$ by 2020 and by $42 \%$ by 2025 ; this was reconfirmed at UNFCCC, COP 17 in Durban in 2011.

21 Earthlife Africa Johannesburg v Minister of Environmental Affairs and Others [2017] 2 All SA 519 (GP), para 91.

22 UNFCCC, art 4(1).

23 CL Orthofer, D Huppmann and V Krey "South Africa after Paris: Fracking its way to the NDCs?" (2019) 7 Frontiers in Energy Research 20; G Cunliffe et al "Comparative analysis of the NDCs of Canada, the European Union, Kenya and South Africa from an equity perspective" (2019, Energy Research Centre, University of Cape Town).

24 See further analysis of these global imperatives below.

25 "Global energy-related $\mathrm{CO}_{2}$ emissions flattened in 2019 at around 33 gigatons, following two years of increases. This resulted mainly from a sharp decline in $\mathrm{CO}_{2}$ emissions from the power sector in advanced economies, thanks to the expanding role of renewable sources (mainly wind and solar PV), fuel switching from coal to natural gas and higher nuclear power output": IEA “Global $\mathrm{CO}_{2}$ emissions in 2019" (11 February 2020), available at: <https://www.iea.org/articles/global-co2-emissions-in-2019> (last accessed 3 May 2021). 
The fourth sobering thought is that, in the Southern African Development Community (SADC) region, South Africa leads in terms of technology, development and research, and should take the initiative to lead towards a sustainable energy future. ${ }^{26}$ This is significant, not least because South Africa also exports electricity to neighbouring countries. The idea of South Africa taking the initiative is not only politically important, but also economically sensible, as renewable energy will become the energy of choice in the future and South Africa can position itself to lead in that area and reap immense economic returns.

A fifth contextual point is that, despite the development of the White Paper on the Renewable Energy Policy of South Africa in 2004, there has been little progress in developing a specific predictable legal framework specifically to anchor the adoption of renewable energy technologies. ${ }^{27}$ Legal reforms towards renewable energy seem to have been superseded by developments, both technologically and in the social, economic and political climate in South Africa. Since 2003, the aims and objectives of renewable energy regulation have fundamentally shifted with changes in the economy, energy supply and demand trajectories. Piecemeal policy interventions such as the Integrated Resource Plan (IRP) (2010-30) and the IRP (2019), ${ }^{28}$ as well as the Electricity Regulations on New Generation Capacity, ${ }^{29}$ have all demonstrated their precariousness as instruments to promote renewable energy. They are inadequate to create the certainty that private investors in search of returns seek. ${ }^{30}$

Therefore, except for the feed-in-tariff ${ }^{31}$ guidelines and regulations, and the National Energy Act 34 of 2008, legal reforms have been half-hearted, with most new regulations having few incentives to promote renewable energy effectively. Regulations to promote renewable energy are ambiguous and discretionary, instead of creating predictable and specific strategies for renewable

26 "South Africa's combination of integrated policymaking, strong regulation, welldesigned incentives for low carbon investment including private investment, greater efficiency and regional integration gives it enviable strength for [diversifying and reducing the environmental impact of the country's energy mix]": IEA "South Africa", available at: <https://www.iea.org/countries/south-africa> (last accessed 3 May 2021).

27 A particularly noticeable small step is the development by the National Energy Regulator of South Africa (NERSA) of "South Africa renewable energy feed-in tariff (REFIT): Regulatory guidelines” (March 2009), available at: <https:/www.gov.za/sites/default/fil es/gcis_document/201409/32122382.pdf> (last accessed 1 June 2021).

28 IRP (October 2019) General Notice 1360 in Government Gazette 42784 (18 October 2019).

29 Electricity Regulations on New Generation Capacity General Notice R399 in Government Gazette 34262 (4 May 2011) made under the Electricity Regulation Act.

30 Recently demonstrated by the refusal by the state-owned utility, Eskom, to sign power purchase agreements (PPAs) with independent power producers (IPPs) after a legitimate procurement process from 2016 to 2018. See L Kruger "Eskom's standoff on SA's renewable energy resources" (2017) 17016 Farmer's Weekly 6; C Yelland and R Lilley "Cloak and dagger drama at the IPP signing" (16 April 2018) Energize, available at: <https://www. ee.co.za/article/drama-at-the-signing-why-did-eskom-refuse-to-sign-the-ppas.html> (last accessed 1 June 2021).

31 NERSA "South Africa renewable energy", above at note 27. 
energy to take-off. ${ }^{32}$ The only visible action is the enactment of the New Generation Capacity Regulations and the shift to the Renewable Energy Independent Power Producer Procurement Programme (REI4P), ${ }^{33}$ detailed exploration of which is the subject of other research. ${ }^{34}$ However, this shift is happening in the context of legislation that was primarily developed to regulate and entrench conventional fossil sources of energy. ${ }^{35}$ Renewable energy procurement in South Africa is a stop-gap measure to backstop the failing coal-powered fleet of the state-owned utility, Eskom. ${ }^{36}$

The National Energy Act seeks to promote integrated energy planning and "to ensure ... increased generation and consumption of renewable energies". ${ }^{37}$ Its approach to energy sources, however, wrongly assumes that renewable sources can compete with established fossil-based sources. That is very optimistic, ${ }^{38}$ but correct when comparing new renewable installations to new fossil fuel plants. To date, Eskom would have used a fifth of the funds sunk into REI4P to generate the same amount of electricity from its established plants. Apart from mentioning the need to increase the use of renewable energy, there are no substantive provisions in the act on how that is to be achieved, especially regulatory certainty and incentives.

Contrary to the principles in the National Energy Act of increasing the share of renewable energy, the government remains committed to nonrenewable sources, ${ }^{39}$ in line with IRP (2019) and the Draft Integrated Energy

32 The renewable energy or source diversity provisions in the National Energy Act are very general, while the mandates in the Electricity Regulation Act are discretionary.

33 "IPP procurement programme" (2012) General Notice 1074 in Government Gazette 36005 (19 December 2012).

34 See generally, Eberhard, Kolker and Leigland "South Africa's renewable energy", above at note 3 .

35 See generally T Murombo "Regulating energy in South Africa: Enabling sustainable energy by integrating energy and environmental regulation" (2015) 33 Journal of Energy E Natural Resources Law 320.

36 IRP (2019), above at note 28 at 44.

37 National Energy Act, preamble.

38 The costs of wind, solar and storage technology are falling but, "the right regulatory and policy frameworks, [are necessary]": International Renewable Energy Agency "The power to change: Solar and wind cost reduction potential to 2025" (2016) at 10. "While energy transition presents opportunities to optimize the allocation of resources through the adoption of new technologies, create jobs through new business models and reduce environmental footprints from the energy value chain, it also poses risks of socioeconomic shocks from ill-informed decisions": World Economic Forum "Fostering effective energy transition: A fact-based framework to support decision-making” (2018) at 10 .

39 "Post 2030, the expected decommissioning of 24,100 MW of coal fired power plants supports the need for additional capacity from clean energy technologies including nuclear": IRP (2019), above at note 28, table 5. See also Centre for Environmental Rights "Environmental justice organisations condemn SA's plans for more coal electricity" (11 October 2019), available at: <https://cer.org.za/news/environmental-justice-org anisations-condemn-sas-plans-for-more-coal-electricity> (last accessed 3 May 2021); 
Plan. ${ }^{40}$ For instance, large fiscal resources have been made available for financing or guaranteeing the expansion of fossil-based energy generation through subsidization. Further plans to increase nuclear generation capacity as per IRP (2019) remain on the cards. ${ }^{41}$ In total 2,500MW of nuclear energy is envisaged under IRP (2019). ${ }^{42}$ Energy regulation has so far focused on maintaining the status quo of promoting energy from fossil fuels in an industry dominated by a heavily subsidized monopoly..$^{43}$

The demand for electricity has increased by a huge margin, to the extent that in 2008 rolling black-outs were inevitable, and the risk persisted well into 2019 and 2020. It has been projected that the demand for energy in South Africa will continue to grow to $77,834 \mathrm{MW}$ by 2030 , with $18,000 \mathrm{MW}$ committed under IRP (2019). ${ }^{44}$ This demand was premised on certain assumptions of growth in gross domestic product, which are now unlikely given the economic slowdown ${ }^{45}$ and Covid-19 pandemic. The new plan however envisages decommissioning of $35,000 \mathrm{MW}$ of electricity generated from coal by $2050 .{ }^{46}$ The lack of a renewables legal framework has partly disrupted efforts to transition to an energy mix with more renewable sources. ${ }^{47}$ This is partly because, in the South African regulatory environment, the country has an obligation to deliver crucial social (equity) and economic (affordability and cost) goals that have often meant overlooking energy sustainability and focusing on delivering on those social and economic goals. ${ }^{48}$ This socio-economic context makes it impractical to propose a wholesale transition to renewable

contd

"Eskom's capacity expansion programme for growth" (9 July 2016), available at: <http:// www.eskom.co.za/news/Pages/Jul9.aspx> (last accessed 3 May 2021).

40 Department of Energy "Draft 2012 integrated energy planning report", published for consultation (June 2013).

41 In line with IRP (2019), on 14 June 2020 the Department of Mineral Resources and Energy published a "Request for information in respect of the nuclear new build power procurement programme" to supply 2,500 MW, sending a strong signal of the government's intention to persist with nuclear procurement if feasible. See: <http://www.energy.gov. za/files/tenders/2020/nuclear-rfi/RFI-Nuclear-New-Build-Power-Procurement-Programme. pdf> (last accessed 1 June 2021).

42 IRP (2019), above at note 28 at 48.

43 There are negligible efforts to force technology. Instead, the focus is on making fossilbased energy cleaner, for example through coal gasification, natural gas as well as increased use of nuclear energy.

44 IRP (2019), above at note 28 at 28 . Id at 47 forecasts an energy mix with approximately $43 \%$ coal, $10.52 \%$ solar photo-voltaic, $0.76 \%$ concentrating solar power, $6.35 \%$ storage, $22.53 \%$ wind, $8.1 \%$ gas, $5.84 \%$ hydro and $2.36 \%$ nuclear.

45 IEA "Global energy review 2020: The impacts of the Covid-19 crisis on global energy demand and $\mathrm{CO}_{2}$ emissions" at 24 .

46 IRP (2019), above at note 28 at 35.

47 The absence of an appropriate legal framework creates market distortions through subsidizing fossil-based energy, entry barriers and the misconception that renewable energy is not cost effective. See Lyster and Bradbrook Energy Law, above at note 12 at 29-30.

48 Socio-economic rights and the need to reduce the number of people without access to energy. 
energy, but rather a better case being made for a balanced energy mix. This context also undercuts current renewables procurement programmes premised on locking the country into above market-price power purchase agreements funded or guaranteed by the government.

Lastly, while the country is conscious of the causal relationship between renewable energy and its capacity to meet social and economic objectives, it emphatically chose to rely on fossil sources to sustain the energy intensive economy. Paradoxically, fossil fuels threaten the health and well-being of citizens. It may have been considered cheaper and faster to promote electrification using fossil power, than first to fund and then deploy renewables commercially. Hence, the slow pace at which renewable energy has been promoted. However, once commercialized, bringing new large coal-fired plants online takes longer than wind or solar, as evidenced by the delays with the Medupi and Kusile new coal projects. ${ }^{49}$ The near-term business case for renewables is now settled but the energy transition cannot happen overnight. ${ }^{50} \mathrm{~A}$ costly renewable procurement programme creates profits for investors who will vanish in the long-term when the whole market becomes unprofitable. By then, the public utility would have been destroyed and the state become saddled with storage, transmission and distribution costs.

It is in this context that this article argues that South Africa has been slow in its approach to renewable energy. By way of background, it must be understood that this tardy movement in South Africa is not by any means an isolated phenomenon. Indeed, many countries have enacted renewable energy legislation, yet there has been slow progress in creating direct international legally binding obligations for countries to promote renewable energy. ${ }^{51}$ There is in fact no international legal instrument promoting renewable energy as such. According to research, "[t]he diverse challenges facing the energy system today cannot be addressed by a single government, industry, company or other institution alone. A broader variety of expertise, convictions and resources are required for effective action ... To progress in energy transition, the world requires a collaborative platform that fosters a systemic approach to solving problems and capturing opportunities". ${ }^{2}$

49 The REI4P programme has demonstrated that renewables have shorter lead times, with many successful Window I projects coming online: M Breytenbach "IPP programmes on track: Eskom" (16 May 2014) Creamer Media's Engineering News, available at: <http://www. engineeringnews.co.za/article/ipp-programmes-on-track-eskom-2014-05-16> (last accessed 3 May 2021).

50 N Healy and J Barry "Politicizing energy justice and energy system transitions: Fossil fuel divestment and a 'just transition'” (2017) 108 Energy Policy 451 at 457.

51 This excludes indirect instruments governing climate change and GHG emissions, or air pollution.

52 World Economic Forum "Fostering effective energy transition: A fact-based framework to support decision-making" (2018, with analytical support from McKinsey and Company) at 5. 
An international regime underpinning the great energy transition is necessary, ${ }^{53}$ despite varied country contexts. Notwithstanding global progress, it has been argued that " $[\mathrm{t}]$ he world's progress on transitioning to sustainable energy has stalled". ${ }^{54}$ This reflects that investment in renewable energy has also plateaued globally. ${ }^{55}$

The analytical context and background provided above is shaped by tensions and complementarities between energy, climate, and environmental and related regulatory spaces such as mining, and social and environmental justice. ${ }^{56}$ This has motivated co-option of the labour movement notion of a "just transition" to energy transition, yet it has its own interpretive complexities. $^{57}$ This foundation enables us now to engage with the central question of this article: why it is necessary to create legal regulations targeted at promoting renewable energy. Some assume that, because South Africa has abundant sun and wind, it can therefore leapfrog to renewable energy with little reflection on the need for an effective and just regulatory regime. ${ }^{58}$

\section{WHY LEGAL REGULATION FOR RENEWABLE ENERGY?}

Academics and researchers have long pondered the justifications for regulation and traced the concept back to the origins of the state and its regulatory agencies. ${ }^{59}$ This includes the evolution of corporate private interests and the public interest that necessitated regulation. Whether law is subsumed under regulation or whether regulation itself is a form of "law in action"

53 See also R Leal-Arcas and A Filis "The fragmented governance of the global energy economy: A legal-institutional analysis” (2013) 6 Journal of World Energy Law and Business 348 at 357.

54 "This impressive progress on accessibility is masking a far wider global failure: our ability to transition to secure, affordable and sustainable energy": World Economic Forum "The world's progress on transitioning to sustainable energy has stalled. Here's how to fix it" (2 May 2019), available at: <https://www.weforum.org/our-impact/the-world-is-failing-onprogress-to-make-energy-systems-environmentally-sustainable-here-s-how-to-fix-it> (last accessed 3 May 2021).

55 Frankfurt School-UNEP Centre / BlombergNEF "Global trends in renewable energy investment 2020" (2020) at 64; R Stubbe "Global clean-energy investments have slowed in 2018" (12 July 2018) Bloomberg Businessweek, available at: <https://www.bloomberg. com/news/articles/2018-07-12/global-clean-energy-investments-have-slowed-in-2018> (last accessed 1 June 2021).

$56 \mathrm{~N}$ Wood and K Roelich "Tensions, capabilities, and justice in climate change mitigation of fossil fuels" (2019) 52 Energy Research E Social Science 114 at 115; E Bellos "Sustainable energy development: How can the tension between energy security and energy transition be measured and managed in South Africa?" (2018) 205 Journal of Cleaner Production 738 at 748.

57 Ibid. See also JM Cha "A just transition for whom? Politics, contestation, and social identity in the disruption of coal in the Powder River Basin" (2020) 69 Energy Research \& Social Science 101657.

58 P Gauché, J Rudman and C Silinga "Feasibility of the WWF renewable energy vision 2030 South Africa: A spatial-temporal analysis” (2015, World Wildlife Fund).

59 M Feintuck "Regulatory rationales beyond the economic: In search of the public interest" in Baldwin, Cave and Lodge The Oxford Handbook, above at note 1, 40. 
remains unclear and the relationship between these two remain controversial. ${ }^{60}$ What is clear, however, is that, while regulation can be effected through law, there are certainly other economic instruments that do not necessarily fit into the law typology. ${ }^{61}$ This versatility of "regulation" thus requires "a transor multi-disciplinary perspective". ${ }^{62}$ A contemporary broad attack on regulation is that (over)regulation is increasingly seen as anathema to economic growth and competitiveness. ${ }^{63}$ At the other end of the spectrum, regulation is necessary to correct the excesses of modern capitalist profit-seeking behaviour. Yet, a functioning energy market can negate the need for regulation altogether.

The conceptualization of law is contested, and the contestation has spread to a discourse that tries to unpack the relationship between law and regulation. In this respect Black rightly points out that, "the exact relationship [between law and regulation], to state the obvious, depends on the conceptualisation of both that is adopted. There is as little and as much agreement as to what 'law' is as there is as to what 'regulation' is". ${ }^{64}$

An exhaustive analysis of the various theories of regulation, as such, is not in the purview of this article; however, law has not featured very highly in the study of regulation. ${ }^{65}$ Hence, Morgan and Yeung conclude that, "existing literature on theories of regulation is largely inattentive to the role of law" and this has led to an underestimation of the "facilitative role of law" in theories of regulation. ${ }^{66}$ This insight captures the underlying thesis of this article. However, as Hutter concludes, as far as regulatory authority is concerned, "[t]aking all of this together it is perhaps not surprising that most regulatory commentators argue for a regulatory mix - embracing both state and non-state sources of regulation - to maximize the potentials of each sector". 67 This rise of "regulatory pluralism" 68 should be taken with

60 "The relationship between law and regulation is unclear. Is law to be understood as a broader enterprise than regulation, or is it narrower?": R Brownsword Rights, Regulation, and the Technological Revolution (2008, Oxford University Press) at 6.

61 Ibid.

62 R Baldwin, M Cave and M Lodge "Introduction: Regulation - The field and the developing agenda" in Baldwin, Cave and Lodge The Oxford Handbook, above at note 1, 1 at 6.

63 Id at 7; H Trebing "Government regulation and modern capitalism" (1969) 3 Journal of Economic Issues 87 at 88.

64 J Black "Critical reflections on regulation" (2002) 27 Australasian Journal of Legal Philosophy 1 at 28 .

65 For further detailed reading on regulation, see generally: E Dal Bó "Regulatory capture: A review" (2006) 22 Oxford Review of Economic Policy 203; GJ Stigler and C Friedland "What can regulators regulate? The case of electricity" (1962) 5 Journal of Law and Economics 1; R Posner "Theories of economic regulation" (1974) 5 Bell Journal of Economics and Management Science 335.

66 B Morgan and K Yeung An Introduction to Law and Regulation: Text and Materials (2007, Cambridge University Press) at 16.

67 BM Hutter The Role of Non-State Actors in Regulation (2006, LSE Research Online) at 14.

68 N Gunningham and D Sinclair "Regulatory pluralism: Designing policy mixes for environmental protection" (1999) 21 Law and Policy 49 at 51. 
caution given its implications for the accountability of regulatory institutions or actors. ${ }^{69}$

It has been argued, however, that "emphasis on the law's facilitative role in regulation may point to a possible limitation of economic conceptions of regulation, which do not explicitly incorporate values other than those concerned with achieving allocative efficiency". ${ }^{70}$ For too long, policy formulation and regulation in the public utilities has been informed by economic theories, with negligible attention to legal and social realities and the role of law in regulation. Economic rationality in the energy market must be tempered by public interest, social and environmental justice-driven legal prescripts to guide energy choices, and conduct. ${ }^{71}$ As McCauley and Heffron conclude, "[t]raditional economics has not yet delivered positive 'just' outcomes for society. This neoliberal viewpoint and its botched drive for competition have led to the current malaise of many sectors in the economy". ${ }^{72}$

Law as a guide to social and economic behaviour must ride on other nonlegal methods of persuasion for corporations and individuals in making choices in relation to energy, climate and the environment. Some theories of regulation support the use of law in regulation to change social and economic behaviour. This article therefore analyses the possible reasons why legal regulation is necessary to promote renewable energy. Generally, there are various reasons why we regulate, and authorities have exhaustively discussed the main arguments for why it is necessary to use regulation. ${ }^{73}$ There has been little research and writing on why and how we should regulate the electricity energy sector in South Africa. Ultimately, the intention in further research is to propose appropriate laws to promote renewable energy within an appropriate, socially-just frame. The general justifications for regulation do apply to the regulation of the electricity sector, ${ }^{74}$ yet interestingly there are also peculiar reasons why regulation has become necessary to promote renewable energy.

In order to understand the motivation for legal regulation, one need only look at the emerging and established global drivers towards renewables, and then discuss them at the local level. What remains clear is that energy should remain a public good, given the need to protect livelihoods in a low-carbon

69 Ibid.

70 Morgan and Yeung An Introduction, above at note 66 at 26.

71 Regulating for a just energy transition should consider energy system technical issues, the environment, labour, energy markets, infrastructure, access and affordability (at household and country levels).

72 D McCauley and R Heffron "Just transition: Integrating climate, energy and environmental justice” (2018) 119 Energy Policy 1 at 2.

73 C Veljanovski "Economic approaches to regulation" and "Strategic use of regulation" in Baldwin, Cave and Lodge (eds) The Oxford Handbook, above at note 1, 18 and 88 respectively.

74 These justifications are rectifying market failures, eliminating externalities, providing public services and promoting competition. 
economy. The role of the state and properly governed public energy utilities remains critical for energy sovereignty, security and access.

\title{
Global environmental and energy challenges as drivers
}

Since the late 1980s, we have been aware of anthropogenic climate change and actions taken so far will be inconsequential unless targets are legally enforced. ${ }^{75}$ The international climate change regime requires a transition to a sustainable economy with stabilized GHG emissions. The Paris Agreement anticipates this within a state's capabilities. For South Africa, failure to take adequate action to reduce GHG emissions from electricity generation by using more renewables could mean various direct and indirect consequences. It is likely that South Africa's trading partners, especially those in Europe, may ultimately introduce some form of green energy profile or carbon footprint into trade agreements. ${ }^{76}$ This could include requirements that products imported into other countries must disclose their energy or carbon footprint through border carbon tax adjustments. ${ }^{77}$ Countries that export goods with a higher carbon footprint would be uncompetitive ${ }^{78}$ regardless of whether or not they are a UNFCCC Annex I country. ${ }^{79}$ Despite this, caution must always be exercised to ensure that developing countries do not undertake reforms simply to accommodate pressures from developed countries. As Braithwaite and Parker argue:

\begin{abstract}
"Intellectual property lawyers head south and east with Western intellectual property statutes tucked in their suitcases, tax lawyers with Western tax codes in theirs. Some of this missionary work is motivated by a desire to spread justice ideals, but mostly it is explicitly funded to help developing countries regulate their societies in ways that will promote economic growth, either for themselves, or for the developed economies that are 'helping' them." 80
\end{abstract}

There is no philanthropy in the global trade system or even more so in renewable energy technologies; developing countries should protect their peoples'

75 The system developed within the framework of the UNFCCC and Kyoto Protocol has achieved minimal impact as member states have been slowly moving away from legal undertakings to political promises in the last three COPs: S Rayner "How to eat an elephant: A bottom-up approach to climate policy" (2010) 10 Climate Policy 615 at 616.

76 See generally Y Dong and J Whalley "Carbon, trade policy and carbon free trade areas" (2010) 33 The World Economy 1073.

77 Department of National Treasury "Reducing greenhouse gas emissions and facilitating the transition to a green economy: Carbon tax policy paper" (2013) at 58-59. See generally, S Bolwig and P Gibbon Emerging Product Carbon Footprint Standards and Schemes and Their Possible Trade Impacts (2009, Risø National Laboratory for Sustainable Energy) at 9.

78 D Lesage, $\mathrm{T}$ van de Graaf and $\mathrm{K}$ Westphal Global Energy Governance in a Multipolar World (2016, Routledge) at 4.

79 D de Jongh, D Ghoorah and A Makina "South African renewable energy investment barriers: An investor perspective” (2014) 25 Journal of the Economic Science Association 15.

80 J Braithwaite and C Parker "Conclusion" in C Scott, N Lacey and J Braithwaite (eds) Regulating Law (2004, Oxford University Press) 269 at 269-70. 
social, economic and environmental rights. The adoption of new technologies must be responsive to the local context and be sustainable. Thus, any legal regulation must enable an energy transition that promotes energy justice, and a fair and equitable outcome. At the regional (SADC) level, by acting now to promote renewable energy, South Africa would be preparing for her future domination of this sector. Countries that take the first steps have the potential to benefit most when new energy technologies become fully commercialized and competitive on a regional and global scale.

Nevertheless, regardless of local priorities, there are several reasons why it is necessary to transition towards renewable energy. These are also drivers for the rising call for global regulation of the energy sector. The main global drivers towards renewable energy are the challenges coming from climate change, ${ }^{81}$ access to affordable energy, ${ }^{82}$ security of supply and the need for alternative sustainable sources of energy. ${ }^{83}$ The UNFCCC is the main treaty under which countries have undertaken to reduce GHG emissions. South Africa is not an Annex I country, and therefore not strictly required to reduce GHGs as such. However, all state parties have minimum obligations under the UNFCCC. ${ }^{84}$ South Africa also committed to voluntary targets in Copenhagen and under the Paris Agreement "intended nationally determined contributions" regime. How is climate change a driver for regulating to promote renewable energy? Policy and legal commitments to reducing GHG emissions and to taking climate action are among the reasons why South Africa should push the energy sector, among other sectors, towards low-carbon energy sources. ${ }^{85}$

The transition to renewable energy cannot be explained by climate change per se, although it is one of the key drivers of the renewable energy clarion call. Mitchell and Woodman contend that a sustainable energy system is much more than reducing GHG emissions: "[i]t will also require technological changes throughout energy systems infrastructure - transmission and distribution networks, supply chains, more advanced metering and appliances as well as more social and institutional changes such as the way consumers treat energy supply or the way that systems management is viewed by policymakers and regulators". 86

81 J Krupa and S Burch "A new energy future for South Africa: The political ecology of South African renewable energy" (2011) 39 Energy Policy 6254 at 6255.

82 UN Sustainable Development Goals "Goal 7: Affordable and clean energy", available at: $<$ https://www.un.org/sustainabledevelopment/energy/> (last accessed 3 May 2021).

83 O Edenhofer The IPCC Special Report on Renewable Energy Sources and Climate Change Mitigation (2011) at 168-69.

84 UNFCCC, art 4; "Copenhagen Accord, Framework Convention for Climate Change", UN doc FCCC/CP/2009/L.7 (2009).

85 Hence the Climate Change Bill of June 2018. See also court sentiments in Earthlife Africa Johannesburg $v$ Minister of Environmental Affairs [2017] 2 All SA 519 (GP), paras 83 and 91.

86 Mitchell and Woodman "Regulation and sustainable", above at note 1 at 572. 
The confirmed link between GHGs from energy production processes and climate change makes the energy sector a key focus area for enabling legal reforms. The global shift towards sustainability implies that, even in the energy sector, countries must transition to low-carbon, but sustainable, energy sources. ${ }^{87}$ The Sustainable Development Goals (SDGs) may not be attained using conventional fossil fuels as these cause the very problems targeted by the SDGs, such as health challenges, environmental sustainability, education and mortality rates. ${ }^{88}$

Internationally, energy security ${ }^{89}$ is a major issue. Energy security encompasses reliability or stability, affordability and general security of supply for industry. ${ }^{90}$ Many countries are faced with the choice of importing energy in a changing global geopolitical environment characterized by conflict over resources and control. ${ }^{91}$ The Southern African Power Pool is a useful regional power market structure that enables countries in southern Africa to share infrastructure and enable electricity trading. ${ }^{92}$ A measure of security does come with regional pooling of resources and joint projects that could stabilize and feed more power into the regional grid. However, recent shortages and security of supply uncertainties have increased insecurity. South Africa faces serious energy security concerns at the domestic level. However, a renewable procurement programme driven by market private capital interests could also threaten future energy security.

Energy security is thus a critical driver of South Africa's efforts to diversify its sources of energy: security of supply has been compromised due to underinvestment in new generation capacity, years of under-priced electricity and huge growth in demand. ${ }^{93}$ The international trends discussed above compel South Africa to take regulatory measures to promote renewable energy sustainably.

\section{Domestic energy sector drivers for renewables}

Electricity demand has grown exponentially, while the supply reserve margin shrank to critical levels over the years. ${ }^{94}$ Eskom's precarious supply situation

87 National Development Plan 163 (objectives on the energy sector).

88 For the SDGs, see DJ Griggs et al "A guide to SDG interactions: From science to implementation" (2017, International Council for Science); D Chirambo "Towards the achievement of SDG 7 in sub-Saharan Africa: Creating synergies between Power Africa, Sustainable Energy for All and Climate Finance in order to achieve universal energy access before 2030" (2018) 94 Renewable and Sustainable Energy Reviews 600.

89 C Winzer "Conceptualizing energy security" (2012) 46 Energy Policy at 36, defining the concept of "energy security".

90 Ibid.

91 The Russian-Ukrainian (European) crisis, conflicts in the Middle East and the uneasy rivalry between the USA and China over extractive resources in Africa are all self-evident.

92 DT O'Leary, J Charpentier and D Minogue "Promoting regional power trade: The Southern African Power Pool" (1998, World Bank).

93 P Lloyd "Restructuring South Africa's electricity supply industry" (2012) 64 Focus 4 at 10.

94 NM Odhiambo "Electricity consumption and economic growth in South Africa: A trivariate causality test" (2009) 31 Energy Economics 635 at 636. 
partly explains the initial commitment behind renewable energy procurement, and the haste in 2019 to resuscitate the programme. There is no energy market in South Africa and the law can play a role in creating and regulating a market ${ }^{95}$ to ensure that services currently provided by Eskom continue to be provided with minimum impact on consumers. Pertaining to this, Barton et al observe that, "[t]he establishment of such new forms of tradable property requires enormous legal input - something overlooked in the economics literature ... Considerable regulatory action is often needed to bring novel markets into being". ${ }^{96}$ A market for energy, coupled with a price on carbon to stimulate appetite for low-carbon sources is dependent on how the law is used to regulate the industry. ${ }^{97}$ This is how economic instruments like the Carbon Tax Act (Act 15 of 2019) can enable the transition to a low carbon energy mix.

Achieving a balance between the need to provide a public service and creating a viable market is the task of regulation through law. It borrows from the orthodox market failure (or absence of a market) justification of regulation, only that regulation will be affected to create market conditions that could result in a sustainable energy system. The current electricity crisis has arisen partly because of the inability of the National Energy Regulator of South Africa (NERSA) to exercise and enforce its legal mandates effectively against the power utility. However, the power utility, Eskom, has long cautioned the government against reducing investment in new generating capacity and routine scheduled or "philosophy" maintenance. ${ }^{98}$

Apart from the supply-side deficits, there are other reasons why regulation is necessary at the domestic level. Tomain argues:

"There are several reasons to regulate energy and industries. First, we should attempt to maximize the potential energy in each resource to have it distributed most efficiently, and to have it consumed most sensibly. Second, regulation can address problems of scarcity, and regulators must pay attention

95 EM Ländner et al "From energy legislation to investment determination: Shaping future electricity markets with different flexibility options" (2019) 129 Energy Policy 1100 at 1101. See also generally, LR Boscán "European Union retail electricity markets in the Green Transition: The quest for adequate design" (2020) 9 Wiley Interdisciplinary Reviews: Energy and Environment e359; WWS Charters "Developing markets for renewable energy technologies" (2001) 22 Renewable Energy 221.

96 B Barton "The theoretical context of regulation" in B Barton et al (eds) Regulating Energy and Natural Resources (2006, Oxford University Press) 11 at 22.

97 South Africa enacted a Carbon Tax Act (15 of 2019), the implementation of which has been controversial in that it is supported by the green movement while mistrusted by labour unions and some industries. For detailed analysis, see $\mathrm{T}$ Alton et al "Introducing carbon taxes in South Africa" (2014) 116 Applied Energy 344; and T Mbadlanyana "The political economy of carbon tax in South Africa: A critical analysis" (2013) 43 Africa Insight 77.

98 L McDaid "Renewable energy: Harnessing the power of Africa?" in DA McDonald Electric Capitalism: Recolonizing Africa on the Power Grid (2012, Routledge) 202 at 206-07. 
to price and the availability and reliability of energy ... The third reason for regulation is to minimize the social, health, and environmental costs of energy production, distribution, and consumption." ${ }^{\text {99 }}$

South Africa is exposed to these multiple domestic pressures. Inefficiency, scarcity, wastage, unreliability, and social and environmental impacts define the current state of the energy sector. ${ }^{100}$ The international pressures pushing the country towards renewable energy are set against countervailing domestic pressures to promote equitable socio-economic development based on affordable fossil energy. A transition to an energy mix dominated by private sector renewables may see energy prices rise to unaffordable levels, thereby requiring unsustainable subsidy levels for the poor. This complex situation leads to policy contradictions and inconsistencies leading to policy and legal uncertainty. ${ }^{101}$ Inequality, incongruities, and the gap between the rich and the poor (the "two economies" dilemma) ${ }^{102}$ make energy policy-making complicated.

With strong legal regulation, policymakers may be able to act without hesitation. In this sense, existing laws that ingrain fossil fuels into the economic fabric of the country are themselves a reason to regulate.

\section{Justification and imperatives in existing laws}

South Africa's main energy law, the National Energy Act, explicitly provides for sustainable energy through the diversification of energy sources. ${ }^{103}$ This peremptory objective is a direct call to incorporate renewable sources, as the country already relies heavily on fossil fuels. The enactment of the National Energy Act is therefore in itself a reason why the country should begin to look at alternative sources. The question then is whether the current plans and policies do in fact promote this important aim of the National Energy Act.

Similarly, the Electricity Regulation Act of 2006 (ERA) aims to "promote the use of diverse energy sources and energy efficiency". ${ }^{104}$ A 2011 Amendment Bill proposed to amend this act to add expressly that this object would be to promote the use of "diverse sources of energy, renewable energy sources, and energy efficiency", but the bill was never passed. ${ }^{105}$ The diversification

99 JP Tomain Ending Dirty Energy Policy: Prelude to Climate Change (2011, Cambridge University Press) at 13.

100 The demand for electricity has frequently exceeded supply, tripping the grid sporadically since 2008 and well into 2020: Department of Energy "National response to South Africa's electricity shortage" (January 2008).

101 Krupa and Burch "A new energy future", above at note 81 at 6258.

102 L Gentle "Escom to Eskom: From racial Keynesian capitalism to neo-liberalism (19101994)" in McDonald Electric Capitalism, above at note 98, 50 at 66 and 71.

103 National Energy Act, sec 2; Electricity Regulation Act, sec 2.

104 ERA, sec 2(e).

105 Electricity Regulation Second Amendment Bill 2011 General Notice 905 in Government Gazette 34870 (19 December 2011) (emphasis added). 
of sources is further bolstered by section 34 of ERA, which empowers the minister of mineral resources and energy to increase capacity by making new generation capacity regulations. This section is an indicator that South Africa recognizes the urgency of the need to increase capacity. Nevertheless, section 34 is not solely aimed at new capacity from renewables and its focus is simply to enable the minister to intervene and direct plans when faced with capacity constraints. Thus, in addition to renewables, ${ }^{106}$ the minister has previously determined that new capacity was to be procured from coal, nuclear and gas. ${ }^{107} \mathrm{~A}$ serious flaw in this legal regime is that it makes energy procurement entirely dependent on ministerial discretion in making determinations. It is doubtful if this was the intention of the law maker. Absurdly, this implies that private sector investors, other spheres of government (such as metropolitan municipalities) and large corporates wanting to generate electricity cannot do so unless there is a determination.

A further flaw of section 34 of ERA is that the energy regulator's power to issue a generation licence is subject to ministerial consent. In other words, the minister, rather than the regulator, has de facto control over who can enter the electricity market and using what sources. This explains the supplementary nature of the REI4P $\mathrm{P}^{108}$ with unnecessary capacity caps. ${ }^{109}$ Furthermore, only Eskom is authorized to buy electricity from independent power producers (IPPs). ${ }^{110}$ This has not only throttled the growth of the renewable electricity sector in South Africa, but also entangled the state and Eskom in unnecessary liability under power purchase agreements. Currently, municipalities and other users cannot buy electricity directly from IPPs, a matter unsuccessfully challenged in court by the City of Cape Town. ${ }^{111}$ The

106 Independent Power Producers Procurement Programme 2012 General Notice 1074 in Government Gazette 36005 (19 December 2012); Renewable Energy IPP Procurement Programme 2015 General Notice 733 in Government Gazette 39111 (18 August 2015).

107 Hence the Baseload IPP Procurement Programme 2012 General Notice 1075 in Government Gazette 36005 (19 December 2012), as amended by General Notice 732 in Government Gazette 39111 (18 August 2015). Nuclear Programme: Determination under sec 34(1) of the Act General Notice R1557 in Government Gazette 40494 (14 December 2016); Gas IPP Procurement Programme 2016 General Notice 602 in Government Gazette 40023 (27 May 2016).

108 IRP (2019), above at note 28 at 44. IRP decision 1 is to: "Undertake a power purchase programme to assist with the acquisition of capacity needed to supplement Eskom's declining plant performance and to reduce the extensive utilisation of diesel peaking generators in the immediate to medium term. Lead-time is therefore key" (emphasis added).

109 Surprisingly, according to IRP (2019), id at 46, the limits on solar photo-voltaic and wind are retained "pending the finalisation of a just transition plan".

110 However, id at 17 states that "Eskom's role as a Buyer under sec 34 of the Electricity Regulation Act will have to be reviewed, taking the ramifications of its unbundling into account". This assumes a successful unbundling exercise under the Department of Public Enterprises "Roadmap for Eskom in a reformed electricity supply industry" (October 2019), available at: <https://www.gov.za/sites/default/files/gcis_document/ 201910/roadmap-eskom.pdf> (last accessed 3 May 2021).

111 City of Cape Town $v$ The National Energy Regulator of South Africa and Another [2020] 
municipality argued that a section 34 ministerial determination is not required or, if it is required, that the provision is unconstitutional. ${ }^{112}$

If the aim of ERA (and regulations for new generation capacity made under it) is to grow South Africa's renewable energy sector, then the regulatory constraints noted above defy logic. The author submits that these legal provisions should be amended or neutralized altogether through a specific renewable energy law aimed at renewables in South Africa's energy mix. The National Energy Regulator Act, analysed in detail elsewhere, also needs reform to strengthen the powers of the regulator. ${ }^{113}$

\section{Domestic environment-specific imperatives}

Environmental challenges in South Africa present an immediate justification for the need to regulate for renewable energy. Generating electricity from fossil fuels contributes to air and water pollution, ${ }^{114}$ environmental degradation from related extractive activities and impacts general well-being. ${ }^{115}$ This could violate section 24(a) of the Constitution of South Africa, 1996 (the Constitution), which provides for a right to an environment not harmful to health and well-being. Apart from the standard reasonableness test, ${ }^{116}$ there are no internal limitations to section 24(a) and therefore any activity or

contd

ZAGPPHC 800 (11 August 2020). The application was dismissed on a technicality, the court directing the City of Cape Town to exhaust cooperative government intergovernmental dispute resolution mechanisms before litigating.

112 The electricity legislation makes everything subject to the minister's determinations; see Constitution of South Africa, secs 26 and 152(1)(b); Local Government: Municipal Systems Act 32 of 2000, secs 23(1) and 73; Local Government: Municipal Structures Act 117 of 1998, sec 84(1)(c); and ERA, sec 27 itself. Further litigation was pre-empted when the government amended the law to permit municipalities, subject to certain financial prudence measures, to procure renewable energy: reg 5(3) of Electricity Regulations on New Generation Capacity, introduced under General Notice 1093 in Government Gazette 43810 (16 October 2020).

113 Murombo "Regulating energy in South Africa", above at note 35.

114 M Holland "Health impacts of coal fired power plants in South Africa" (2017, GroundWork) at 15-16; "Coal kills: Research and dialogue for a just transition" (2018, GroundWork) at 10-11; Hichange Investments (Pty) Ltd $v$ Cape Produce (Pty) Ltd t/a Pelt Products 2004 (2) SA 393 (E), holding that expecting employees to work in conditions exposed to odorous sulphur dioxide violated environmental rights; Tergniet and Toekoms Action Group and 34 Others v Outeniqua Kreosootpale (Pty) Ltd [2009] ZAWCHC 6, on what constitutes "health".

115 MEC: Department of Agriculture, Conservation and Environment $v$ HTF Developers (Pty) Limited 2008 (2) SA 319 (CC), interpreting broadly the meaning of well-being; Minister of Health and Welfare $v$ Woodcarb (Pty) Ltd 1996 (3) SA 155 (N) 164F, holding that exposure to smoke violates the right to an environment not harmful to health and well-being.

116 For different analyses of the "reasonableness test", see LJ Kotzé "Phiri, the plight of the poor and the perils of climate change: Time to rethink environmental and socioeconomic rights in South Africa?" (2010) 1 Journal of Human Rights and the Environment 135 at 154-55; F Biermann et al "The fragmentation of global governance architectures: A framework for analysis" (2009) 9 Global Environmental Politics 264. 
conduct that threatens someone's health or well-being is potentially a constitutional violation.

Given the effects of producing energy from fossil fuels, it can be argued that the current mode of producing electricity is unconstitutional. Indeed, this is a possible interpretation and could be a basis for demanding that South Africa legally regulate the sector to move towards sources that do not unreasonably affect people's health and well-being. Despite this prima facie interpretation, the government continues to approve new coal power plants and permit the operation of existing ones. The Constitution does not envisage the cessation of any activity that may in fact affect health and well-being; rather, the Constitution prohibits activities that go beyond what is reasonable in a human environment. ${ }^{117}$ Therefore, a measure of pollution is inevitable in the process of generating electricity.

Furthermore, section 24(b) of the Constitution requires the government to take reasonable legislative and other measures to prevent pollution, among other obligations, while promoting justifiable social and economic development. This right is qualified by the criterion of reasonableness. The duty to promote ecologically ${ }^{118}$ sustainable development mandates the consideration of the energy profile of South Africa to see how it can drive sustainable development. ${ }^{119}$ The current development paradigm is underpinned by the heavy use of energy, mostly produced from fossil fuels. To shift from the current, energy intensive, economic development model, to one that is low-carbon and less polluting, requires a shift in the regulatory approach itself. Pollution prevention and sustainable use of non-renewable resources ${ }^{120}$ are justifications for targeted regulation to promote renewable energy. The current energy system causes extensive pollution throughout the coal value chain and the energy production cycle. This pollution is a legitimate target of section 24 of the Constitution.

To elaborate, coal mining causes extensive physical environmental damage, water (acid mine drainage) and air pollution, and reduces arable land for other uses, such as agriculture and biodiversity conservation. ${ }^{121}$ Coal power plants

117 Fuel Retailers Association of Southern Africa v Director-General: Environmental Management, Department of Agriculture, Conservation and Environment, Mpumalanga Province 2007 (6) SA 4 (CC).

118 It has been argued that the definition of sustainable development in sec 2 of the National Environmental Management Act 107 of 1998 (NEMA) is ultra vires the Constitution, sec 24(b), as it is not qualified with "ecologically". In other words, the concept of sustainable development in NEMA is broader than that envisaged by the Constitution: $\mathrm{M}$ van der Linde and E Basson "Environment" in S Woolman et al Constitutional Law of South Africa (2014, Juta) 50.1 at 50.26, footnote 131.

119 Fuel Retailers Association above at note 117, paras 44-45, 58-59, 61, 72-74, 76 and 79-80.

120 These objectives are also encapsulated in the principles of environmental management in NEMA, sec 2.

121 Director: Mineral Development, Gauteng Region and Another $v$ Save the Vaal Environment and Others 1999 (2) SA 709 (SCA); Harmony Gold Mining Co Ltd v Regional Director, Free State Department of Water Affairs and Others 2014 (3) SA 149 (SCA); Kebble $v$ The Minister of 
use a lot of water for washing and cooling. Regulation is necessary to curb the negative effects of using fossil fuels. This legal regulation must be embedded in the principles that underpin section 24 of the Constitution as expanded in section 2 of the National Environmental Management Act 107 of 1998. Current energy and mining legislation unfavourably promotes an energy sector supported by fossil fuels. The developmental agenda anchored around capitalism must be decoupled from its demands for energy. ${ }^{122}$

If sustainable development justifies a shift towards renewable energy, which the author argues it is, does this mean that all renewable energy is necessarily sustainable? Not necessarily. Yet it is desirable for renewable energy sources to be low-carbon and geared towards sustainability. Whether or not renewable sources are themselves sustainable does not affect the argument that we can better promote sustainable development through renewable energy than through non-renewable fossil fuels. ${ }^{123}$ This thesis entails legal regulation to encourage the use of renewables and discourage overreliance on fossil fuels. The need to internalize the environmental externalities of fossil fuels is a cogent reason to demand legal regulation towards renewable energy. If we internalize the externalized impacts of fossil fuels, it becomes apparent that renewables are more sustainable than fossil fuels.

Apart from the regulatory imperatives noted in the preceding paragraphs, other environmental problems caused by the energy industry call for legal regulation to promote renewable energy. Air and water pollution from electricity generation, aggravating global climate change, domestic health and environmental effects, are all indicators that environmental pollution control regulation has been ineffective in disincentivizing the use of fossil fuels. ${ }^{124}$

contd

Water Affairs and Forestry 2007 JDR 0872 (SCA): all cases dealing with the impacts of mining on the environment.

122 See in detail FV Bekun, F Emir and SA Sarkodie "Another look at the relationship between energy consumption, carbon dioxide emissions, and economic growth in South Africa" (2019) 655 Science of the Total Environment 759; Q Wang, R Jiang and L Zhan "Is decoupling economic growth from fuel consumption possible in developing countries? A comparison of China and India" (2019) Journal of Cleaner Production 806.

123 Renewable sources have their own environmental impacts. See "Final environmental impact assessment for the proposed Bokamoso photovoltaic solar energy facility near Leeudoringstad, registration division HP, North West Province" Department of Environmental Affairs ref no: 14/12/16/3/3/2/559 Environamics (2014) 82; "Environmental impact assessment process draft environmental impact report proposed castle wind energy facility near De Aar, Northern Cape Province" Department of Environmental Affairs ref no: 14/12/16/3/3/2/278 Savannah (2014) at 101-93, detailing the geophysical, visual, avifauna, noise, heritage and ecological impacts of a wind farm. See generally S Szewczuk "Review of the wind energy activities in South Africa" (2014, Council for Scientific and Industrial Research) 1.

124 For instance, despite promulgation of more stringent atmospheric emissions standards, Sasol, among other energy companies, challenged the standards on the basis that they are not technologically and financially able to comply in the set time frames: Sasol Synfuels (Pty) Ltd and Others $v$ Minister of Water and Environmental Affairs and Others (High 
Pollution control legislation must be complemented by effective legislation to reduce the use of polluting non-renewable primary sources. This entails the mandating of technology and emission standards ${ }^{125}$ in renewable energy laws, which is currently not the case with the National Energy Act and ERA, which are the primary instruments for electricity regulation. Reform of energy law is therefore necessary to open the South African electricity supply industry to competition from the private sector and own-use public institutions.

A legal framework for electricity, which protects the industry from competition, could impede socio-economic development, and is one of the key areas necessary for reform to enable the country to meet its developmental objectives. The electricity supply industry needs more competition and private actors, without completely surrendering provision of a public service to profitseeking private independent power producers. This sums up why regulatory intervention is necessary in South Africa's energy markets. If the energy sector is to play its enabler role in socio-economic development, reform is inevitable. Without such reform, it will be difficult for IPPs and the private sector to bring investment into the renewable energy sector. As witnessed under the REI4P, falling solar and wind bid prices could mean reduced profits and consequent disinterest by investors in the long-term.

Legal certainty is necessary to enable effective implementation of South Africa's renewable energy policies. Yet, creating legal regulatory certainty is not pure law-making, but a fraught political process, ${ }^{126}$ as shown by the dithering of the past two decades. Local pressures to move towards renewable energy are self-evident in South Africa and countries with similar economies, yet transforming these pressures into drivers of hard law has been a challenge in the electricity supply industry.

\section{THE TIPPING POINT: 2008-20 ELECTRICITY SHORTAGES}

Electricity shortages are directly attributable to various factors. Shortages indicate that, without an adequate supply margin, electricity can easily become a

contd

Court, Gauteng Division, Pretoria) case no 36444/14 (21 June 2014). In 2019 the government backtracked on promulgating stiffer atmospheric emission standards and returned to relaxed standards for $\mathrm{SO}_{2}$; see "Listed activities and associated minimum emission standards identified" under sec 21 of the National Environmental Management: Air Quality Act, 2004 (Act 39 of 2004) General Notice 893 in Government Gazette 37054 (22 November 2013), as last amended by General Notice 687 in Government Gazette 42472 (22 May 2019); “Amendments to the listed activities and associated minimum emission standards identified" under sec 21 of the National Environment Management: Air Quality Act, 2004 Government Gazette 42013, Government Notice 1207 (31 October 2018).

125 Standards and emission limits from environmental legislation are peripheral and secondary.

126 Helm Energy, the State, above at note 5 at 11. 
critical resource. ${ }^{127}$ The insecurity engendered by the 2008 blackouts spurred the government, as the major shareholder in Eskom, to scramble for resources to fast-track the build programme ${ }^{128}$ under which the generation capacity was to be ramped up. However, measures to mitigate the risk of supply shocks after 2008 were a case of too little too late, given the construction lead times involved in building new coal power plants. ${ }^{129}$ This led to the regular deployment of costly short-term interventions to reduce demand or increase costly peak supply. ${ }^{130}$ This led to a precariously stable supply period from 2009 to 2014, but the system came under stress again from 2014 to 2015 and then $2019^{131}$ to 2020 . These intermittent supply stress periods since the 2008 debacle betray the persistent lack of security in the South African electricity system. ${ }^{132}$ The slow construction at the new coal plants Medupi and Kusile $^{133}$ has been plagued by several challenges, the cumulative effect of which has been to push full deployment dates further ahead, with huge cost overruns. Complete units have serious faults that require costly repairs. However, it is relevant that the lack of energy security exemplified by electricity shortages over the past 13 years is a prime driver of the need for the electricity sector to diversify and be opened to the private sector.

It is now a common concern that South Africa faces an energy crisis that has recurred since 2008, with a consistent drop in the electricity availability factor. ${ }^{134}$ This is enough to spur the country to review its energy laws to enable

127 B Becker and D Fischer "Promoting renewable electricity generation in emerging economies" (2013) Energy Policy 446 at 451.

128 A loan from the World Bank enabled Eskom to fund construction at Medupi.

129 The Medupi power plant is more than five years behind schedule and the cost has increased from R80 billion in 2007 to over R200 billion in 2019: L Donelly "Medupi and Kusile: Costly and faulty" (15 February 2019) Mail \& Guardian (Johannesburg), available at: <https://mg.co.za/article/2019-02-15-00-medupi-and-kusile-costly-and-faulty/> (last accessed 3 May 2021).

130 Diesel powered plants are costly to run and decimated Eskom's 2015 budget: "Eskom spent R47.4bn on diesel in the past ten years" (6 May 2019) Engineering News 1.

131 This was despite the Eskom (System Operator) "Medium-term system adequacy outlook 2016-2021" report (at 16), forecasting possible stabilization from 2018. See C Fabricious et al "Medium-term system adequacy outlook 2020-2024" (30 October 2019), available at: <http://www.eskom.co.za/Whatweredoing/SupplyStatus/Doc uments/MediumTermSystemAdequacyOutlook2019.pdf> (last accessed 3 May 2021) at 18.

132 Since late 2019, Eskom has openly warned that the country is heading for harder times: U Nkanjeni "Stages 6 to 8 load-shedding: What it means and how it affects you" (10 December 2019) Times Live (South Africa).

133 The last units were projected to come online in May 2020 and September 2022, respectively.

134 Despite prevarications by the government and Eskom, it is admitted that South Africa is now in a constant state of electricity crisis: see P Burkhardt "Electricity shortages cost South Africa R118bn last year" (23 January 2020) Independent Online, available at: <https:// www.iol.co.za/business-report/companies/electricity-shortages-cost-south-africa-r118bn-lastyear-41160983> (last accessed 1 June 2021). 
a "just transition"135 to energy security. This article argues that legal reforms are necessary, not only to promote a transition to renewables, but also to present an opportunity to design a sustainable and socially just energy system. ${ }^{136}$ This would address most of the international and domestic imperatives for regulating the sector discussed above. Policy and political pronouncements on opening the market, unbundling Eskom and a roadmap to rescue Eskom ${ }^{137}$ are all ineffective without an effective targeted legal intervention to increase renewables. The essential elements of such a law are detailed below, where the role of law is outlined.

Direct legal regulatory intervention has become urgent in view of the convergence of global, domestic, implementation and governance challenges that are all pushing South Africa into a long-term electricity supply deficit. Climate change, security of supply concerns, corruption and the inefficiency of Eskom's monopoly call for the opening of the electricity supply industry to the private sector beyond the limited scope of the REI4P.

\section{ROLE OF LEGAL REGULATION IN PROMOTING RENEWABLE ENERGY}

It is proving difficult for renewable energy to penetrate the energy system and markets in South Africa and other developing countries. This is not because of its inherent limitations or disadvantages per se, but largely due to the exclusionary effect of existing energy laws, which were developed to root conventional fossil fuels in centralized and vertically integrated energy systems. It is arguably a lesser challenge for renewables to overcome economic barriers, than it is for these sources to overcome legal and institutional obstacles that have little to do with the sustainability potential of renewables. ${ }^{138}$ This challenge is pronounced in developing countries where the energy

135 M Swilling, J Musango and J Wakeford "Developmental states and sustainability transitions: Prospects of a just transition in South Africa" (2016) 18 Journal of Environmental Policy and Planning 650. See also N Healy and J Barry "Politicizing energy justice and energy system transitions: Fossil fuel divestment and a 'just transition'” (2017) 108 Energy Policy 451 at 452 , cautioning that "a just energy transition is intensely political - not simply a technological or indeed a socio-technical matter". IRP (2019), above at note 28 at 44-45 defines "just transition", adopting the International Labour Organisation "Guidelines for a just transition towards environmentally sustainable economies and societies for all" (2015), available at: <https://www.ilo.org/wcmsp5/groups/public/-ed_emp/-emp_ ent/documents/publication/wcms_432859.pdf> (last accessed 1 June 2021).

136 A Rosemberg "Building a just transition: The linkages between climate change and employment" (2010) 2 International Journal of Labour Research 125 at 142-44 highlights the essential features of a just transition as: sound investments in low-emission and labour-intensive technologies; social and employment impact assessment; social dialogue within democratic consultation; upskilling; social protection; and local economic diversification planning.

137 Department of Public Enterprises "The roadmap for Eskom in a reformed electricity supply industry" (October 2019).

138 The barriers to renewable energy are extensively analysed in T Murombo "Legal and 
systems are not yet fully liberalized. Where the market has been liberalized, it may be easier for renewable sources to penetrate the market, as the market is probably more active. This contrasts sharply with the situation in some developing countries where the energy systems are still largely in the hands of state-owned utilities that monopolize not only the industry, but also how it is regulated and influences policy directions. ${ }^{139}$

Stimulating a renewable energy market can be effected through a framework Renewable Energy Act underpinned by key minimum features. The objects of the act must be to promote a gradual transition that is founded on sustainable energy, energy security, socially equitable change aligned with section 24 of the Constitution, climate change policy and the national development plan. Secondly, a framework law should be embedded in principles of energy justice, environmental justice and climate justice, as governing norms for participatory decision-making. Thirdly, while providing incentives and possible state support, the framework law should promote socially owned renewable energy and prevent the use of public funds to support a private for-profit renewable energy corporation. The latter would receive regulatory support through removal of ministerial discretion in determining when and how much more capacity is required (section 34 of ERA). Social ownership includes participation by a redundant fossil fuel labour force, unions, municipalities and local government, and communities. Lastly, the proposed framework act should consolidate NERSA's mandate to promote renewable sources through technical regulation (licensing). The ideal law would create a framework within which progressive existing laws can be implemented.

Free market economic regulation of the market alone is insufficient to change the energy market in favour of renewable energy. A framework renewable energy law, in addition to providing more certainty, relative to non-legal regulation, has the potential for more direct impact towards the regulatory goals, hence countries that have succeeded in deploying renewable energy have done so on the strength of positive legislation. ${ }^{140}$ There is intentionality and direction in legal regulation.

\section{CONCLUSION}

This article has demonstrated the evolution of regulation over time and the drivers that could push South Africa to regulate for renewable energy. It has

contd policy barriers to renewable and sustainable energy sources in South Africa" (2016) 9 The Journal of World Energy Law \& Business 142.

139 This is exemplified by the role Eskom is playing in the design and implementation of the REI4P programme in South Africa. Power purchase agreements can only be concluded with Eskom. Outside this programme, it remains a challenge for IPPs to break into the market.

140 "New policies, especially in the USA, China and the EU, are supporting this effort": Edenhofer The IPCC Special Report, above at note 83 at 173. 
also advocated a framework for understanding the need for a targeted renewable energy law. It explained why current approaches to promoting renewable energy have met with mixed results, resulting in legal uncertainty and potentially locking the state into unsustainable debt under power purchase agreements. Any legal reforms to promote renewable energy should deconstruct the current neo-liberal initiatives relying on public funds to promote an emerging private renewable energy global elite. Once established and bolstered by contractual state guarantees of unsustainable energy prices, this elite could lead to an energy market that further marginalizes the poor, with high electricity prices to sustain investor interest. All this while masquerading as the champions of climate change mitigation. The current REI4P is a recipe for future energy insecurity and an unjust transition funded by the state. It should be redesigned with the public goods nature of electricity in mind and guided by a framework law.

The incumbency of fossil fuels, bolstered by existing energy laws, continues to shape the change agenda and potential energy reforms. The imprecision of the mandates of departments and agencies relevant to renewable energy is reinforced by current laws. This possibly saves the state's interest in maintaining the public service nature of electricity guaranteed by a public utility. Existing energy legislation and energy resource planning tools do not show the urgency of the need to increase the renewables share of the market. The procurement programme implemented to date should be reconfigured.

Legal regulation in this context can achieve better results by providing certainty and security of investment. ${ }^{141}$ In addition to a framework law, this entails legislative amendments to remove government discretion, opening the procurement process to give consumers choice to purchase electricity from diverse sources (removing the single-buyer model), but in so doing protecting environmental rights and the poor's access to affordable energy. Such legal reforms should be informed by the need to enable a just but sustainable transition, while properly phasing out fossil fuels. Ultimately, a transition to a low-carbon energy future is by its nature a process, not an overnight event.

\section{CONFLICTS OF INTEREST}

None

141 A McHarg and A Ronne "Reducing carbon-based electricity generation: Is the answer blowing in the wind?" in DN Zillman et al Beyond the Carbon Economy: Energy Law in Transition (2008, Oxford University Press) 288. 